\title{
ANALYSIS OF TRIBOLOGIC PROPERTIES OF SELECTED STEELS
}

\author{
Marian Kučera, Juraj Rusnák, Milan Kadnár, Vlastimil Malý
}

Original scientific paper This contribution brings an evaluation of basic material $\mathrm{C} 45$ heat treated and hardened, $16 \mathrm{MnCr} 5$ as basic material carburized and hardened and weld deposits of selected additional hardened materials. Results obtained for basic material are compared with results on materials of surfaced layers. This enables us to predict certain characteristics of friction pairs under conditions of particular friction node. The tribologic experiment was carried out on device, which belongs to the category of "pin-disk" test devices. The resistance of the selected materials was evaluated concerning weight loss and energy issues. It was observed that combinations of material C508 + C64 and material RD1 give the best results for both categories of test samples under the experimental conditions. Wear resistance of this combination of materials was higher than $43 \%$. The wear resistance was calculated from energy consumed to remove one unit of metal from the surface.

Keywords: adhesive wear; calculations; pin-disk test; wear resistance

Analiza triboloških svojstava odabranih čelika

Izvorni znanstveni članak $\mathrm{U}$ ovom se prilogu daje procjena osnovnog materijala C45 toplinski obrađenog i kaljenog, $16 \mathrm{MnCr} 5$ kao osnovnog materijala pougljičenog i kaljenog te materijala zavara izabranih dodatnih kaljenih materijala. Rezultati dobiveni za osnovni material uspoređeni su s rezultatima dobivenim na materijalima površinskih slojeva. To nam omogućuje predviđanje nekih karakteristika tarnih parova u uvjetima određenog tarnog čvora. Tribološki eksperiment proveden je na uređaju koji pripada kategoriji "trn-disk" uređaja za ispitivanje. Otpornost izabranih materijala procijenjena je u odnosu na gubitak težine i pitanja energije. Ustanovljeno je da kombinacije materijala C508 + C64 i materijala RD1 daju najbolje rezultate za obje kategorije ispitnih uzoraka u eksperimentalnim uvjetima. Otpornost na trošenje te kombinacije materijala bila je viša od 43 \%. Otpornost na trošenje je izračunata je iz energije potrošene da bi se otklonila jedna jedinica metala s površine.

Ključne riječi: adhezivno trošenje; otpornost na trošenje; proračuni; trn-disk test

\section{Introduction}

Friction is an important physical effect and requires a lot of theoretical and experimental work to be well understood. A systematic approach is necessary for complex solution of friction and related attrition in both the theoretical and experimental spheres $[1 \div 12]$. Regarding tribologic properties of materials, the right choice of material or material pair, the geometric shape, roughness, etc. are all important [13]. For tribometry, it is a question of choosing the right test device and test methods as well as the right shape and size of the test samples and their preparation [14]. Choosing an appropriate approach to solve the problem of adhesive friction and related wear is also very important [15]. The specific working conditions of agricultural machinery affect its working life. This lifetime is sometimes short as a result of heterogeneous forms of breaking of the components and destruction of the components' surface. A relatively short working life of machinery and device components in agricultural production is caused by excessive wear, variability of the work regime, an aggressive environment [16]. For the purpose of solving the durability problem it is necessary to recognize basic factors and relations, which determine defects and decrease the operating reliability [17]. The problem is even more complicated in case of a need of replacing the worn surface. As it concerns here a tribologic node with weld deposit, the knowledge of material properties, the effect of alloying elements and the effect of the welding technique on weld deposit properties are all of the maximum importance [18]. Adhesive wear is a complicated process as surface layers of friction pairs of material are damaged during interaction of undulating bearing surfaces [19]. The nature of the deformation depends not only on the penetration depth of irregularities into the other part's surface but also on the radius of the particular penetrating irregularity [20]. In case of elastic deformation, faults in surface layers are of the high-cycle contact fatigue pattern. In case of plastic deformation, the surface attrition is determined by low-cycle contact fatigue. Adhesive wear is thus a result of micro-connections in the surface layers [21]. This paper deals with the possibility of predicting friction pair behaviour based on results of tribologic experiments

\section{Materials, methods and samples}

We paid great attention to the selection of appropriate materials. We analyzed 186 different components of shaft or pin type of various agricultural devices (tractor, harvester, straw-cutter, mobile machines, etc.) with worn functional parts of cylindrical shape [22] and we found that 20 different types of steel are used for production of these components:

3 types of steel class E 295, S 355J0, E 355

4 types of steel class C15E, C45, C55, C60

2 types of steel class $37 \mathrm{MnSi} 5,42 \mathrm{MnV} 7$

6 types of steel class $37 \mathrm{Cr} 4,16 \mathrm{MnCr} 5,20 \mathrm{MnCr} 5,34 \mathrm{Cr} 4$, $36 \mathrm{Mn} 5,67 \mathrm{SiCr} 5$

4 types of steel class 25CrMo4, 42CrMo4, 30Cr2V, $42 \mathrm{CrV} 6$

1 type of steel class $18 \mathrm{NiCr} 5-4$

From the group of materials the following types of steel were selected for purposes of the experimental wear resistance test:

steel C45 as a representative of steel types used after heat treatment and inductive hardening, 
steel $16 \mathrm{MnCr} 5$ as a representative of steel used for production of components with carburized and hardened surface.

For the purpose of the experiment, material $\mathrm{C} 45$ and $16 \mathrm{MnCr} 5$ were selected as representatives of steel types used for manufacturing of "shaft-type" components with treated and hardened surfaces. These materials were compared with weld deposits made of additional material C508, C64, 54SiCr5 [17] and RD1. The samples were hard surfaced on materials $\mathrm{C} 45$ and $16 \mathrm{MnCr} 5$ of tubular shape using welding technique in shielding gas MIG/MAG, by the unifilar and by the two-wire process. Wire C 64 with higher content of carbon was used as additional cold wire. Chemical composition of used additional materials is as follows (\% weight):

C $508-0,25 \mathrm{C} ; 0,9 \mathrm{Mn} ; 0,9 \mathrm{Si}$;

C $64-0,7 \mathrm{C} ; 0,7 \mathrm{Mn} ; 0,25 \mathrm{Si} ; 0,03 \mathrm{P} ; 0,06(\mathrm{~S}+\mathrm{P}) ; 0,22$

$\mathrm{Cu} ; 0,1 \mathrm{Cr} ; 0,1 \mathrm{Ni}$

RD $1-0,3 \div 0,5 \mathrm{C} ; 1,0 \div 1,5 \mathrm{Mn} ; 0,2 \div 0,5 \mathrm{Si} ; 0,9-1,5 \mathrm{Cr}$; $0,1 \div 0,3 \mathrm{Ti} ; 0,03 \mathrm{P} ; 0,03 \mathrm{~S} ; 0,5 \div 0,8 \mathrm{Mo} ; 0,3 \div 0,5 \mathrm{~V}$; $1,0 \div 1,5 \mathrm{~W}$

$54 \mathrm{SiCr} 6-0,5 \div 0,6 \mathrm{C} ; 0,5 \div 0,8 \mathrm{Mn} ; 1,3 \div 1,6 \mathrm{Si} ; 0,5 \div 0,7 \mathrm{Cr}$; $0,3 \mathrm{Cu} ; 0,5 \mathrm{Ni} ; 0,035 \mathrm{P} ; 0,035 \mathrm{~S}$

Selection of test method, test device and evaluation method of results was performed following the definition of wear [23, 24] and adhesive process [25], which says that wear is an undesirable change in the surface or the size of a solid entity that is caused either by interaction of functional surfaces or by interaction of functional surface and medium, which starts the wear. Wear is demonstrated by the removal or transfer of surface elements by mechanical means. Based on this definition we decided to use adhesive wear test without greasing. Tests were elaborated on a test device of type TE 97/A - Fig. 1 which belongs to the category of "pin-disk" devices with flat contact of friction node elements.

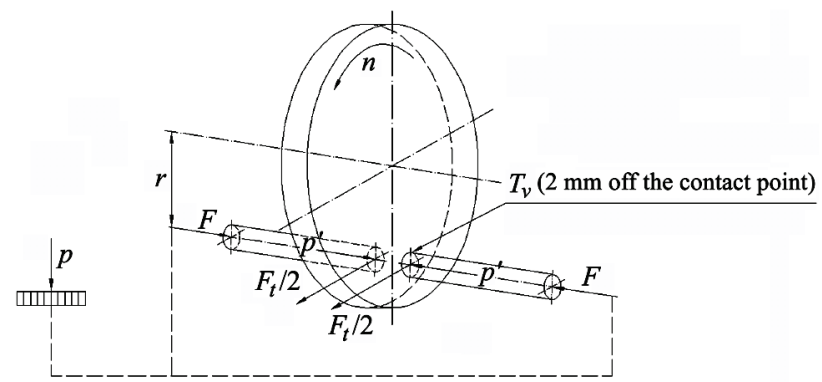

Figure 1 Illustration of working principle of device TE 97/A

The producer of the test device is Research Institute of Welding in Bratislava [RIW]. The test device is suitable for comparison tests of selected materials. Fundamentally, test samples of pin shape are imprinted to facing surfaces of a rotating disk using a hydraulic cylinder and constant force. Pins were manufactured from material $\mathrm{C} 45$ and $16 \mathrm{MnCr} 5$ plus other weld deposit material as mentioned above. The counter part was made of material C15E, Fig. 3. Test conditions were chosen in accordance with test methodology elaborated by RIW. The method is based on measuring the energy consumption for defined wear. This technique is suitable for comparison of wear resistance of basic materials with wear resistance of weld deposits [21]. The following values for test parameters were selected for the adhesive wear test without greasing:

- contact pressure 1,4 $\mathrm{MPa}$

- compressive force on the pin $74,3 \mathrm{~N}$

- $\quad$ surface speed of the test radius $3,2 \mathrm{~m} / \mathrm{s}$

- $\quad$ exposure time $15,30,45,75 \mathrm{~s}$

- material of the counterpart dimension of the sample steel C15E $8 \times 50 \mathrm{~mm}$

Hard surfacing was performed on experimental welding machine ENZ-100 using $\mathrm{CO}_{2}$ as shielding gas [18]. The samples for the adhesive wear resistance test were welded on a bar of $105 \mathrm{~mm}$ in diameter made of basic materials by the rotating welding technique. Samples with weld deposits $20 \div 25 \mathrm{~mm}$ in diameter were prepared this way. Surfacing parameters are listed in Tab. 1. After cooling, the samples were shaped into a ring which was then divided into 12 parts. Further latheturning prepared the active part of the sample which was imbedded into the counterpart and fixed. The thickness of the weld deposit on the surface after completion was 2 $\mathrm{mm}$. Four pairs of test samples were prepared from each weld deposit. After heat treatment, the elements were modified and lathed to final diameter of $8 \mathrm{~mm}-$ Fig. 2 .

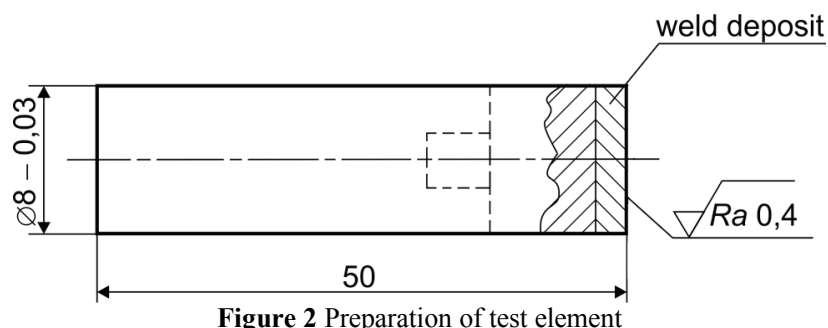

During the test, changes in friction force were recorded by a tensometric scanner RIW. The record of the course of friction force enables to determine maximum friction force, mean value of the friction force, frictional work and friction factor. The wear of the samples was detected by direct observation before and after the test. After proper degreasing and drying, samples were weighed on analytic scales MEOPTA with sensitivity $0,05 \mathrm{mg}$. The result of the wear test on device TE 97/A gives a diagram showing the extent of wear versus time of the test. This way of sample preparation guaranteed that the active part of the samples, especially in case of weld deposits, will correspond with real surfaces. Cross comparison of different sample materials was a possible thanks to the material of the counterpart being the same in each sequence of the test. The samples made of basic materials $\mathrm{C} 45$ and $16 \mathrm{MnCr} 5$ have the same shape as samples with weld deposits. The characteristics of test elements, the status of their heat treatment and temper are shown in Tab. 2. The hardness was measured on the front of the samples i.e. at the point of interaction of the sample with the testing disk. Hardness tester MEOPTA VICKERS with a load of spire $F=295,3 \mathrm{~N}$ was used for measuring. 
Table 1 Parameters of hard surfacing of samples for wear test without greasing AW - arc wire, CW - cold wire

\begin{tabular}{|c|c|c|c|c|c|c|c|c|c|}
\hline \multicolumn{3}{|c|}{ Additive material } & \multicolumn{2}{|c|}{$\begin{array}{l}\text { Speed of feeding } \\
(\mathrm{m} / \mathrm{min})\end{array}$} & \multirow{2}{*}{$\begin{array}{l}\text { Current hard } \\
\text { surface flow } \\
\text { (A) }\end{array}$} & \multirow{2}{*}{$\begin{array}{c}\text { Arc voltage } \\
\text { (V) }\end{array}$} & \multirow{2}{*}{$\begin{array}{l}\text { Rotation speed of } \\
\text { spindle }\left(\mathrm{min}^{-1}\right)\end{array}$} & \multirow{2}{*}{$\begin{array}{l}\text { Weld deposit rate } \\
\qquad(\mathrm{mm} / \mathrm{min})\end{array}$} & \multirow{2}{*}{$\begin{array}{c}\mathrm{CO}_{2} \\
\text { consumption } \\
(1 / \mathrm{min})\end{array}$} \\
\hline$A W$ & $C W$ & $\begin{array}{c}\varnothing A W / \varnothing C W \\
(\mathrm{~mm})\end{array}$ & $A W$ & $C W$ & & & & & \\
\hline C508 & - & $1,2 / 0$ & 4,7 & - & 165 & 20 & 2,5 & 5 & 12 \\
\hline C508 & C64 & $1,2 / 0,93$ & 3,4 & 2,4 & 115 & 20 & 1,7 & 5 & 12 \\
\hline $2 \times \mathrm{C} 508$ & - & $2 \times 1,2 / 0$ & 2,0 & - & 145 & 20 & 2,2 & 5 & 12 \\
\hline $54 \mathrm{SiCr} 6$ & - & $1,5 / 0$ & 2,5 & - & 145 & 20 & 1,7 & 5 & 12 \\
\hline RD1 & - & $1,6 / 0$ & 3,5 & - & 160 & 23 & 1,5 & 4,5 & 15 \\
\hline
\end{tabular}

\section{Results and discussion}

For the tests without greasing, we derived the quantity of friction work from the value of the friction force at given time and its contribution to weight loss coefficient $K^{*}$. A value $K^{*}$ is a coefficient of tribologic capacity of weld deposits (materials). It represents the quantity of friction work needed for detachment of a unit mass of material $[29,30]$. Comparing the rate of wear and friction work to reference material we get a $K_{\mathrm{N}}$ value, which is referred to as the coefficient of relative tribologic capacity of weld deposit. Beside these, our test type enables definition of:

- $\quad$ ratio of friction coefficient to weight loss

- coefficient $K^{*}$ to mass loss

- $\quad$ coefficient $K_{\mathrm{N}}$ to mass loss

Value $K_{\mathrm{N}}$ characterizes the physical nature of detachment of surface particles during friction. We observed mass loss as a function of time on device TE
97/A (Fig. 1). Results were obtained by weighing the samples before and after the test.

$$
\Delta m=m_{0}-m_{1}, \quad \mathrm{~g}
$$

We detected the wear rate at exposure times of 15, 30, 45, 75 seconds. Fig. 4 presents the results of adhesive wear test without greasing on device TE 97/A.

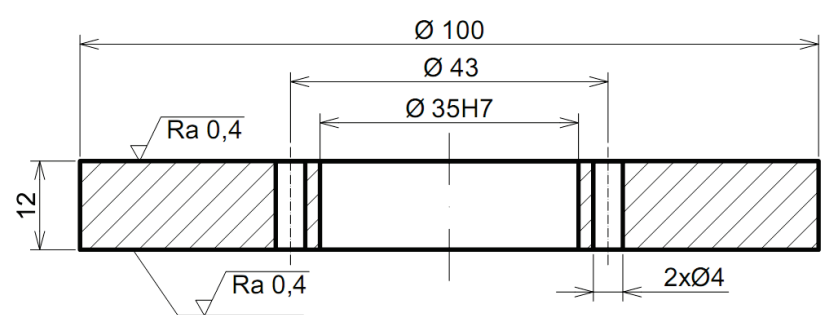

Figure 3 Illustration of shape and dimensions of the disk for adhesive wear test without greasing.

Table 2 Characteristics of samples for wear test without greasing

\begin{tabular}{|c|c|c|c|c|}
\hline $\begin{array}{l}\text { Sample } \\
\text { no. }\end{array}$ & $\begin{array}{l}\text { Basic } \\
\text { material }\end{array}$ & Additive material & Heat treatment & $\begin{array}{c}\text { Surface hardness } \\
\text { (HV) }\end{array}$ \\
\hline 1 & $\mathrm{C} 45$ & C 508 & Hardening $850^{\circ} \mathrm{C} /$ water,tempering $170^{\circ} \mathrm{C} / 1 \mathrm{~h}$. $/$ air & 554 \\
\hline 2 & C 45 & C $508+C 64$ & Hardening $850^{\circ} \mathrm{C} /$ water,tempering $170^{\circ} \mathrm{C} / 1 \mathrm{~h}$. $/$ air & 598 \\
\hline 3 & $\mathrm{C} 45$ & $2 \times \mathrm{C} 508$ & Hardening $850^{\circ} \mathrm{C} /$ water,tempering $170^{\circ} \mathrm{C} / 1 \mathrm{~h}$./air & 527 \\
\hline 4 & C 45 & - & Hardening $850^{\circ} \mathrm{C} /$ water,tempering $170^{\circ} \mathrm{C} / 1 \mathrm{~h}$. $/$ air & 606 \\
\hline 5 & $16 \mathrm{MnCr} 5$ & C $508+$ C64 & Hardening $850^{\circ} \mathrm{C} /$ water,tempering $170^{\circ} \mathrm{C} / 1 \mathrm{~h}$. $/$ air & 637 \\
\hline 6 & $16 \mathrm{MnCr} 5$ & $54 \mathrm{SiCr} 6$ & Hardening $860^{\circ} \mathrm{C} /$ oil,tempering $170^{\circ} \mathrm{C} / 1 \mathrm{~h}$./air & 675 \\
\hline 7 & $16 \mathrm{MnCr} 5$ & RD 1 & - & 530 \\
\hline 8 & $16 \mathrm{MnCr} 5$ & - & Carburized, Hardening $830^{\circ} \mathrm{C} /$ oil,tempering $200^{\circ} \mathrm{C} / 1 \mathrm{~h}$./air & 842 \\
\hline
\end{tabular}

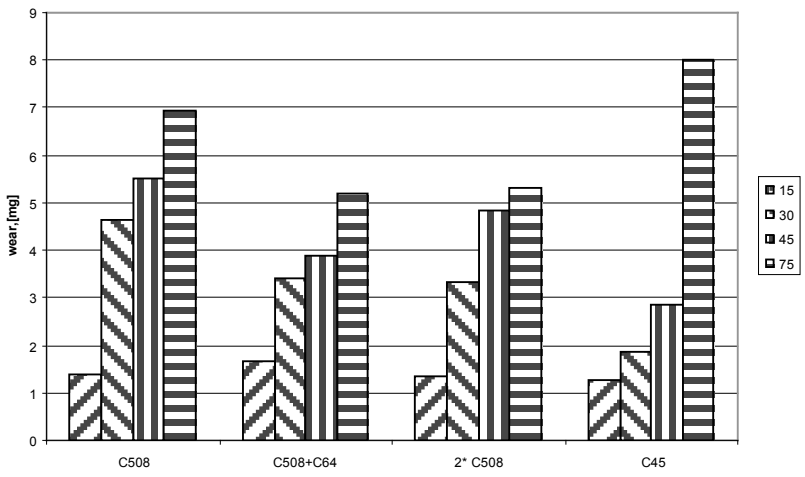

Figure 4 The wear vs exposure time for selected group of test steel C 45

To simplify the evaluation of results, two groups of samples were formed. The first group involves hardened samples meaning that basic material was hardened and weld deposits for this material were heat treated, and inductively hardened as well. The second group involves carburized and hardened materials whereby only the basic material carburized and hardened. Weld deposits for this material, except RD 1, were hardened after being made.

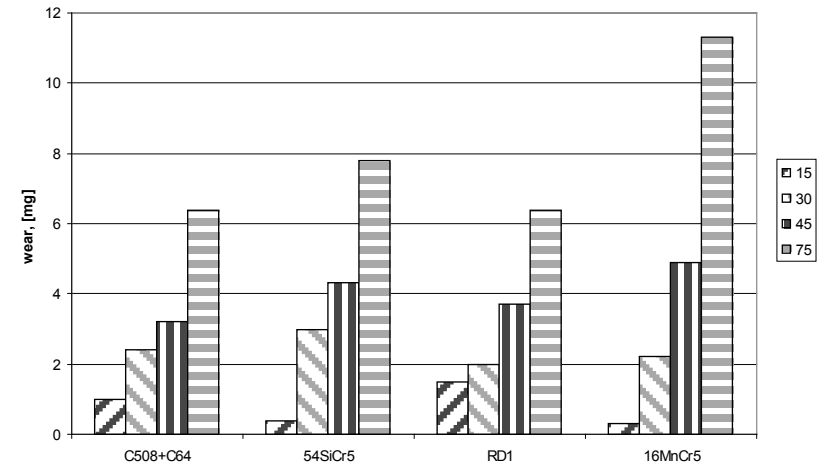

Figure 5 The wear vs exposure time for selected group of test steel $16 \mathrm{MnCr} 5$

Based on results shown in Fig. 4 and Fig. 5 it is possible to describe the behaviour of test samples under experimental conditions. As shown in Fig. 4 the highest wear rate from the whole group of samples was measured for sample no. 4 and exposure time of $75 \mathrm{~s}$. The lowest wear was measured for the same sample and exposure time of $15 \mathrm{~s}$. The wear rate of all samples at $15 \mathrm{~s}$ was 
approximately the same. For other exposure times the wear rates are as shown in the figure. The highest overall wear rate (sum of wear rates for all exposure times) was reported for sample no. 1 and the lowest wear rate was measured in case of sample no. 4. For samples no. 2 and 3 we measured approximately the same wear rate as for sample no. 4. Based on Fig. 5 we state that the highest wear rate was again reported for the basic material, sample no. 8 and exposure time of $75 \mathrm{~s}$. The lowest wear rate was reported for the same sample and of $15 \mathrm{~s}$ exposure time. The wear rate of other materials at exposure time of $75 \mathrm{~s}$ is substantially lower. For exposure time of $30 \mathrm{~s}$ and of $45 \mathrm{~s}$ the wear rate of all samples is very similar. The lowest was measured in case of sample no. 7 and the highest for sample no. 8. The highest overall wear rate (sum of wear rates for all exposure times) was measured for sample no. 8 and the lowest for sample no. 5. The wear rate of sample no. 7 is approximately the same as for sample no. 5. In laboratory conditions, mass loss of weld deposits $m_{0}$ was observed on devices, which enable observing the value of friction force $F_{\mathrm{T}}$ during loading by constant force $F_{\mathrm{N}}$ at given time $t$. Time $t$ is proportional to the friction path $L$. i.e. $\mathrm{d} L=v \mathrm{~d} t$ and then we may calculate work $W$ as follows:

$$
W=\int_{0}^{t} F_{\mathrm{T}} v \mathrm{~d} t .
$$

When relating the friction work to unit weight (volume) of worn weld metal, we get the relation:

$$
K^{*}=\frac{W}{m_{0}}, \mathrm{~J} \cdot \mathrm{kg}^{-1}
$$

If we relate values of the wear $m_{0}$ and friction work $W$ to etalon material, then it may be stated:

$$
K_{\mathrm{N}}=\frac{K_{\mathrm{s}}^{*}}{K_{\mathrm{r}}^{*}}=\frac{\frac{W_{\mathrm{s}}}{m_{0 \mathrm{~s}}}}{\frac{W_{\mathrm{r}}}{m_{0 \mathrm{r}}}}=\frac{W_{\mathrm{s}}}{W_{\mathrm{r}}} \cdot \frac{m_{0 \mathrm{r}}}{m_{0 \mathrm{~s}}},
$$

where: $W_{\mathrm{s}}$ - friction work of the sample, $\mathrm{J} ; W_{\mathrm{r}}-$ friction work of reference sample, $\mathrm{J} ; m_{0 \mathrm{~s}}-$ wear of sample, $\mathrm{g} ; m_{0 \mathrm{r}}$ - wear of reference sample, g.

Tab. 3 shows calculated values of the coefficient of tribologic capacity of weld deposits $K^{*}$ and the coefficient of relative tribologic capacity of weld deposits $K_{\mathrm{N}}$. The $K_{\mathrm{N}}$ criterion allows for the physical basis of detachment of particles from the surface during the friction process and enables assessment of weld deposits for tribologic use. To assess the suitability of weld deposits using coefficients of tribologic capacity we proceeded with two material groups. Tab. 3 shows the power consumed for detachment of unit of material in the process of friction and wear. This energy involves the transfer of abrasive elements from pin on disk and vice versa as well as the transfer back. The highest $\mathrm{K}$ coefficient value was reported for sample no. 7, which is weld deposit made with tubular wire RD1, in spite of its hardness being the lowest among all. The lowest $\mathrm{K}$ coefficient value was reported for sample no. 8 , basic material $16 \mathrm{MnCr} 5$, in spite of its hardness being the highest. As shown in table 3 hardness is not determining in the process of friction and wear as far as power consumption is concerned. Considering sample no. 8 with its structure and chemical composition, we state that the structure based on martensite puts up less resistance against abrasion than for material of sample no. 7 which is RD 1, which is made of tough structure with complex carbides. The same applies to sample no. 4 vs sample no. 2 . K coefficient values for other materials are

\begin{tabular}{|c|c|c|c|c|c|}
\hline Sample no. & Material & Heat treatment & Hardness / HV & $K^{*} /\left(\mathrm{J} \cdot \mathrm{kg}^{-1}\right) \times 10^{8}$ & $K_{\mathrm{N}} /-$ \\
\hline 1 & C 508 & Hardening & $554 \div 620$ & 2,382 & 1,536 \\
\hline 2 & C $508+$ C 64 & Hardening & $598 \div 626$ & 3,841 & 2,478 \\
\hline 3 & $2 \times \mathrm{C} 508$ & Hardening & $527 \div 586$ & 3,062 & 1,976 \\
\hline 4 & $\mathrm{C} 45$ & Hardening & $606 \div 644$ & 2,446 & 1,578 \\
\hline 5 & C $508+$ C 64 & Hardening & $637 \div 671$ & 2,898 & 1,869 \\
\hline 6 & 54SiCr6 & Hardening & $675 \div 752$ & 2,558 & 1,650 \\
\hline 7 & RD 1 & - & $493 \div 530$ & 3,124 & 2,015 \\
\hline 8 & $16 \mathrm{MnCr} 5$ & $\begin{array}{c}\text { Cemented } \\
\text { and hardening }\end{array}$ & $842 \div 897$ & 2,371 & 1,529 \\
\hline etalon & $\mathrm{C} 15 \mathrm{E}$ & - & $160 \div 180$ & 155 & 1 \\
\hline
\end{tabular}
given in Tab. 3.

Table 3 Chart of hardness as measured, $K^{*}, K_{\mathrm{N}}$

Table 4 Chemical composition (\% weight)

\begin{tabular}{|c|c|c|c|c|c|c|c|c|c|c|c|c|}
\hline Weld deposit & $\mathrm{C}$ & $\mathrm{Mn}$ & $\mathrm{Si}$ & $\mathrm{P}$ & $\mathrm{S}$ & $\mathrm{Cr}$ & $\mathrm{Ni}$ & $\mathrm{Mo}$ & $\mathrm{V}$ & $\mathrm{Cu}$ & $\mathrm{Ti}$ & $\mathrm{W}$ \\
\hline C508 & 0,28 & 0,66 & 0,65 & 0,02 & 0,02 & 0,58 & 0,03 & 0,02 & - & 0,17 & - & - \\
\hline $2 \times \mathrm{C} 508$ & 0,28 & 0,82 & 0,82 & 0,017 & 0,014 & 0,72 & 0,05 & 0,02 & 0,01 & 0,08 & - & - \\
\hline 54SiCr6 & 0,44 & 0,78 & 0,64 & 0,02 & 0,02 & 0,71 & 0,08 & 0,01 & 0,01 & 0,21 & - & - \\
\hline C508+C64 & $0,32 \div 0,35$ & $0,70 \div 0,75$ & $0,59 \div 0,67$ & $0,017 \div 0,026$ & $0,017 \div 0,021$ & $0,6 \div 0,7$ & $0,05 \div 0,06$ & $0,01 \div 0,02$ & 0,01 & $0,08 \div 0,021$ & - & - \\
\hline RD 1 & 0,31 & 1,01 & 0,29 & 0,02 & 0,13 & 0,95 & - & 0,56 & 0,43 & - & 0,015 & 1,06 \\
\hline
\end{tabular}

Tab. 4 indicates that chemical composition of samples with weld deposits made of RD1 enables the formation of complex carbides in the structure of the steel. This leads to higher wear resistance with regard to power consumption needed for detachment of metal components.

\section{Conclusion}

This paper presents the results of tribological experiments performed using the device TE 97/A. This device belongs to the category of "pin - disc" devices. The tests of friction and wear without lubrication are 
performed using this device. The tests basically simulate a short-term absence of the lubricant in the friction node. Basic materials $\mathrm{C} 45$ and $16 \mathrm{MnCr} 5$ were used for the tests - these materials are used for manufacturing agricultural machinery components. These materials were compared to selected materials of welded layers in two groups. The experiments were assessed in terms of hardness, weight loss and energy consumption for each sample of material. The results of experiments demonstrate the suitability of material assessment for tribological purposes in terms of energy consumed in the process of wear. It was shown that the hardness of material is not the decisive determinant affecting the wear resistance in given conditions. Based on the results we may conclude that the chemical composition and especially the structural state of the surface layers had a significant effect. Probably for this reason the best results were achieved in layers welded with additional material RD1 and with combination of materials C508+C64.

\section{Acknowledgement}

Experiments were carried out under the project support science and research VEGA: 1/1064/11: Analysis of processes of loading of friction pairs in tribologic experiment conditions and their effect on properties of selected materials.

\section{References}

[1] Sharma, V. et al. Multi response optimization of process parameters based on Taguchi-Fuzzy model for coal cutting by water jet technology. // International Journal of Advanced Manufacturing Technology. 56, 9-12(2011), pp. 1019-1025.

[2] Agunsoye, J. O.; Talabi, S. I.; Bello, O. Wear characteristics of heat-treated Hadfield austenitic manganese steel for engineering application. // Advances in Production Engineering \& Management. 10, 2(2015), pp. 97-107. DOI: 10.14743/apem2015.2.195

[3] Gupta, A. et al. Critical Investigation of Wear behaviour of WC Drill Bit Buttons. // Rock Mechanics and Rock Engineering. DOI: 10.1007/s00603-012-0255-9

[4] Devaraju, A.; Elayaperumal, A.; Venugopal, S.; Kailas, S. V.; Alphonsa, J. Investigation on the High Vacuum Tribological Characteristics of Surface Treated Nuclear Grade Stainless Steel Type AISI $316 \mathrm{LN}$ at 25 to $500{ }^{\circ} \mathrm{C}$. // Strojniski vestnik-Journal of Mechanical Engineering. 57, 12(2011), pp. 927-935. DOI: 10.5545/sv-jme.2010.260

[5] Senatore, A. et al. Effects of couple stresses on the unsteady performance of finite lubricated bearings. // Lubrication Science. 55, 2(2009), pp. 141-149

[6] Nadolny, K.; Kaplonek, W. Design of a device for precision shaping of grinding wheel macro and microgeometry. // Journal of Central South University of Technology. // 19, 1(2012), pp. 135-143. DOI: 10.1007/s11771-012-0982-9

[7] Trzepiecinski, T.; Lemu, H. G. Frictional Conditions of AA5251 Aluminium Alloy Sheets Using Drawbead Simulator Tests and Numerical Methods. // Strojniski vestnik-Journal of Mechanical Engineering. 60, 1(2014), pp. 51-60. DOI: $10.5545 /$ sv-jme.2013.1310

[8] Hryniewicz, T. et al. SIMS analysis of hydrogen content in near surface layers of AISI 316L SS after electrolytic polishing under different conditions. // Surface \& coatings technology. 205, 17-18(2011), pp. 4228-4236

[9] Ruggiero A et al. Approximate Analytical Model for the Squeeze-Film Lubrication of the Human Ankle Joint with Synovial Fluid Filtrated by Articular Cartilage // Tribology
Letters. 41, 2(2010), pp. 337-343. DOI: 10.1007/s11249-0109710-5

[10] Hrynievicz T, Rokosz, K. Analysis of XPS results of AISI $316 \mathrm{~L}$ SS electropolished and magnetoelectropolished at varying conditions. // Surface \& Coatings Technology. 204, 16-17(2010), pp. 4228-4236. DOI: 10.1016/j.surfcoat.2010.02.005

[11] Mishra, A. Frictional characterization of teak wood dustfilled epoxy composites. // Advances in Production Engineering \& Management. 9, 3(2014), pp. 111-118. DOl: 10.14743/apem2014.3.180

[12] Vocel, M.; Dufek, V. et al. Tření a opotřebení strojních součástí. Praha, SNTL 1976.

[13] Czichos, H. Tribologi. A System Approach to the Science and Technology of Friction. Amsterdam, Elsevier 1978.

[14] Kučera, M. Analýza poznatkov zo skúšania tribologických vlastností vybraných materiálov. // Zborník z medzinárodnej vedeckej konferencie "Nové trendy v konštruovaní a v tvorbe technickej dokumentácie 2004", Nitra, May 2004, pp. 75-80.

[15] Brendel, H. et al. Tribotechnika, Praha, SNTL, 1984.

[16] Buckley, D. H. Surface Effects in Adhesion, Friction, Wear and Lubrication. Amsterdam, Elsevier 1981.

[17] Kučera, M. Vlastnosti vrstiev navarených v ochrane CO2 určených pre renováciu $\mathrm{v}$ pol'nohospodárstve, KDP, SPU Nitra, 1991

[18] Dzimko, M.; Schwab, P. Aspekty spol'ahlivosti tribologických systémov. Sympózium "Intertribo 1984", DT ČSVTS Bratislava, 1984.

[19] Blaškovič, P.; Čomaj, M. Renovácia naváraním a žiarovým striekaním. STU v Bratislave, 2006.

[20] Kragelskij, I. V. Trenije i iznos. Moskva, Mašinostrojenije, 1968.

[21] Suchánek, J. Návrh směrnice pro volbu a aplikace povrchových úprav pro zvýšení odolnosti dvojic materiálů proti adhezivnímu opotrěbení. Výskumná správa, Praha, SVUM, 1984.

[22] Bowden, F. P.; Tabor, D. Reibung und Schmierung fester Körper. Berlin, Springer Verlag, 1959. DOl: 10.1007/978-3642-92754-6

[23] Kučera, M.; Rusnák, J. Štúdium tribologických vlastností materiálov nanesených na povrch vybranými technológiami navárania. Monografia. SPU v Nitre, 2008.

[24] Kučera, M. Analýza trecích dvojíc a skúšky opotrebenia materiálov. // Zborník vedeckých prác Nové trendy v konštruovaní a v tvorbe technickej dokumentácie 2006, 25. máj 2006, Nitra: Slovenská polnohospodárska univerzita, 2006, pp. 59-64.

[25] Friction, Wear and Lubrication Terms and definitions, Paris, OECD 1968.

[26] Blaškovič, P. et al. Hodnotenie tribologickej únosnosti návarov. // Sympózium Intertribo. Vysoké Tatry, April 1990, DT ČSVTS Bratislava, pp. 38-45.

\section{Authors' addresses}

\section{Marian Kučera}

\section{Juraj Rusnák}

Faculty of Engineering,

Slovak University of Agriculture in Nitra,

tr. A. Hlinku 2, 94901 Nitra, Slovakia

\author{
Milan Kadnár \\ Vlastimil Malý \\ Faculty of Engineering, \\ Slovak University of Agriculture in Nitra, \\ tr. A. Hlinku 2, 94901 Nitra, Slovakia \\ E-mail: milan.kadnar@uniag.sk
}

